American Journal of Environmental Sciences 5 (4): 468-474, 2009

ISSN 1553-345X

(C) 2009 Science Publications

\title{
An Assessment of Blasting Vibrations: A Case Study on Quarry Operation
}

\author{
${ }^{1}$ Alessandro Giraudi, ${ }^{1,2}$ Marilena Cardu and ${ }^{3}$ Vladislav Kecojevic \\ ${ }^{1}$ DITAG-Department of Land, Environment and Geo-Engineering, Polytechnic di Torino, \\ 24 Corso Duca degli Abruzzi, PA 10129, Turin, Italy \\ ${ }^{2}$ National Council of Researches, Turin, Italy \\ ${ }^{3}$ The Pennsylvania State University, \\ 154 Hosler Building, University Park, PA 16802-5000, USA
}

\begin{abstract}
Problem statement: One of the major environmental concerns related to blasting operation in mining and civil engineering projects is ground vibration. Approach: This study presented an assessment of ground vibrations caused by the blasting experiments at a marlstone quarry in northern Italy. The primary goal of this study was to determine the vibration level in order to protect dwelling area adjacent to the quarry. Based on the data obtained from the field, a new equation for the level of ground vibrations was proposed. Results: A comparative analysis between the results obtained by the new equation and common empirical predictors currently used in blasting practice was also carried out. Conclusion: Results indicated that a new equation may be used as a reliable predictor of the vibration level for the studied quarry.
\end{abstract}

Key words: Rock blasting, environment, marlstone quarry, ground vibrations, peak particle velocity

\section{INTRODUCTION}

The purpose of blasting operations is rock fragmentation. It provides appropriate rock material granulation or size that is suitable for loading and transportation. The blasting process and usage of explosives, however, remain a potential source of numerous human and environmental hazards. Singh and Singh $^{[1]}$ indicate that fragmentation accounts for only $20-30 \%$ of the total amount of explosive energy used. The remainder of the energy is wasted away in the form of ground vibrations, air-overpressure and flyrock. The specific problem associated with ground vibrations represents the human response to them. A recent study completed by Raina et al. ${ }^{[2]}$ indicates the degree of human response to blast vibrations and air-overpressure. In addition, blasting vibrations may cause a significant damage to nearby buildings or various structures.

Ground vibrations are acoustic waves that propagate through the rocks ${ }^{[3]}$. They differ from the ground vibrations caused by earthquakes in terms of seismic source, amount of available energy and travelled distances $^{[4]}$. Usually, parameters such as velocity, displacement and acceleration of particles are recorded during the vibration measurements ${ }^{[5]}$. According to the same author, vibration velocity represents a wave induced velocity of a particle in the media.
Bhandari ${ }^{[6]}$, Rossmanith et al..$^{[7]}$ and Valdivia et al. ${ }^{[8]}$ indicated the significance of several variables whose modifications can influence vibration reduction and improvement of blasting operations. Specifically, Bhandari $^{[6]}$ classified the factors with influence on vibrations as controllable and uncontrollable. Those controllable influences include the blast geometry, type of explosive used, steaming, priming and initiation, while uncontrollable factors are geological conditions and initiation timing errors. A detailed study on blasting parameters that affect the ground vibration and air blast is given by Nicholls et al. ${ }^{[9]}$.

The peak particle velocity (ppv) is considered to be reliable predictor for ground vibrations caused by blasting. This predictor takes into the consideration that the total energy of ground motion generated around a blast varies directly with weight of explosives detonated and it is inversely proportional to the square of distance from the blasting point ${ }^{[10]}$.

The text that follows describes (i) the existing standards and predictors used to estimate blasting vibrations, (ii) a new equation that was derived from the field observations, (iii) a case study on estimation of blasting vibrations for the marlstone quarry in northern Italy and (iv) the comparative study on results obtained by applying the both a new and existing equations.

Corresponding Author: Alessandro Giraudi, DITAG-Department of Environment and Geo-Engineering, Politecnico di Torino, Land, 24 Corso Duca degli Abruzzi, PA 10129, Turin, Italy Tel: +39-011-090-7655 


\section{MATERIALS AND METHODS}

There are several empirical equations that are used in blasting operations to estimate peak particle velocity. The most common equations are shown in Table 1. In these equations, $\mathrm{D}$ is distance between the center of the explosive charge and measuring unit in meters and cpd is charge per delay in kilograms. Values of $\mathrm{K}$, alpha, $\mathrm{n}$ and $\mathrm{m}$ are empirical constants which can be determined by regression analysis and they are based on the measurements of vibration data. Procedure for the determination of these empirical values was covered by the numerous researchers ${ }^{[2,16,17,19-21]}$ and it will not be repeated in this study.

Proposed predictor for blasting vibrations: Based on the analysis of field data, a simple predictor is proposed for the estimation of peak particle velocity (ppv):

$$
\operatorname{ppv}=\mathrm{K} \cdot\left[\frac{\mathrm{D}^{2}}{\left(\mathrm{cpd} \cdot \mathrm{t}_{\mathrm{det}}\right)^{1 / 2}}\right]^{\mathrm{n}}
$$

Where:

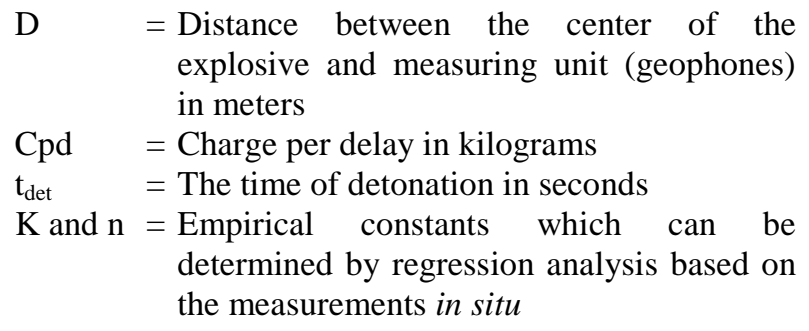

\begin{tabular}{|c|c|}
\hline $\mathrm{USBM}^{[11]}$ & $\mathrm{ppv}=\mathrm{K} \cdot\left(\frac{\mathrm{D}}{\mathrm{cpd}^{1 / 2}}\right)^{\mathrm{n}}$ \\
\hline Davies et al..$^{[12]}$ & $\mathrm{ppv}=\mathrm{K} \cdot \mathrm{D}^{\mathrm{n}} \cdot \mathrm{cpd}^{\mathrm{m}}$ \\
\hline Langefors-Kihlström ${ }^{[13]}$ & $\mathrm{ppv}=\mathrm{K} \cdot\left(\frac{\mathrm{cpd}^{1 / 2}}{\mathrm{D}^{3 / 4}}\right)^{\mathrm{n}}$ \\
\hline Ambraseys-Hendron ${ }^{[14]}$ & $\mathrm{ppv}=\mathrm{K} \cdot\left(\frac{\mathrm{D}}{\mathrm{cpd}^{1 / 3}}\right)^{\mathrm{n}}$ \\
\hline Indian standard ${ }^{[15]}$ & $\mathrm{ppv}=\mathrm{K} \cdot\left(\frac{\mathrm{cpd}}{\mathrm{D}^{2 / 3}}\right)^{\mathrm{n}}$ \\
\hline Ghosh-Daemen ${ }^{[16]}$ & $\mathrm{ppv}=\mathrm{K} \cdot\left(\frac{\mathrm{D}}{\mathrm{cpd}^{1 / 2}}\right)^{\mathrm{n}} \cdot \mathrm{e}^{-\alpha \cdot \mathrm{D}}$ \\
\hline Central mining research institute ${ }^{[17]}$ & $\mathrm{ppv}=\mathrm{n}+\mathrm{K} \cdot\left(\frac{\mathrm{cpd}^{1 / 2}}{\mathrm{D}}\right)$ \\
\hline Rai et al. ${ }^{[18]}$ & $\mathrm{cpd}=\mathrm{K} \cdot\left(\mathrm{ppv} \cdot \mathrm{D}^{2}\right)^{\mathrm{n}}$ \\
\hline
\end{tabular}

Table 1: List of the existing equations for estimation of ppv
The Distance (D) is squared because the body waves travel on the free surface and have a squared decay in a homogeneous material ${ }^{[16,20]}$. Assuming a cylindrical explosive geometry for long charges, several researchers including Duvall and Petkof ${ }^{[11]}$, Duvall and Fogelson $^{[22]}$, Duvall et al. ${ }^{[23]}$ and Daemen et al. ${ }^{[24]}$ concluded that any linear dimension should be scaled with the square root of the charge weight. The time of detonation $\left(t_{\text {det }}\right)$ is tentatively introduced in the equation (1) with the aim to evaluate potential improvements in the calculation of ppv. In fact, depending on the type of explosive, its Velocity Of Detonation (VOD, in $\mathrm{m} \mathrm{sec}^{-1}$ ) is of the same order of magnitude as the propagation speed of the waves in the rock. Therefore, a detonation cannot be considered as an instantaneous and punctual event: Instead, it develops over time and space ${ }^{[25]}$.

The time of detonation is defined as:

$$
\mathrm{t}_{\mathrm{det}}=\frac{\mathrm{N} \cdot 1}{\mathrm{VOD}}
$$

Where:

$\mathrm{N}=$ Number of explosive cartridges in the boreholes

$1=$ Length of each cartridge, in $\mathrm{mm}$

VOD $=$ The velocity of detonation, in $\mathrm{m} \mathrm{sec}^{-1}$

The charge per delay (cpd) is calculated as follows:

$\mathrm{cpd}=\mathrm{N} \cdot 1 \cdot \phi^{2} \cdot \frac{\pi}{4} \cdot \rho_{\mathrm{e}}$

Where:

$\phi=$ Charge diameter, in $\mathrm{mm}$

$\rho_{\mathrm{e}}=$ Explosive density, in $\mathrm{kg} \mathrm{m}^{-3}$

Substituting the equations (2) and (3) into equation (1), ppv is calculated as follows:

$\mathrm{ppv}=\mathrm{K} \cdot\left[\frac{2 \cdot \mathrm{D}^{2} \cdot \mathrm{VOD}^{1 / 2}}{\mathrm{~N} \cdot 1 \cdot \phi \cdot\left(\pi \cdot \rho_{\mathrm{e}}\right)^{1 / 2}}\right]^{\mathrm{n}}$

The equation shows that ppv does not depend only on charge per delay (cpd), but also on Velocity Of Detonation (VOD). It means that, in addition to an explosive weight initiated per delay, the properties of explosive also become important.

Case study: The experimental blasts were carried out in a marlstone quarry located near Lecco, northern Italy. The primary goal was to determine the vibration level in order to protect dwelling area adjacent to the quarry. 
The marlstone is a sedimentary rock primarily composed of clay, mud, sand, $\mathrm{CaCO}_{3}$ and $\mathrm{MgCO}_{3}$. The basic rock properties for the studied quarry include specific gravity of $2500-2555 \mathrm{~kg} \mathrm{~m}^{-3}$ and unconfined compressive strength of 55-65 $\mathrm{MPa}$. The tensile strength (from bending tests) ranges from 2-5 $\mathrm{MPa}$ and shear strength is $7 \mathrm{MPa}$. The rock is not abrasive, moreover, it has an elastic-brittle behavior and rough fracture surfaces.

The distance from blasting site to surrounding buildings was $200 \mathrm{~m}$ and it is likely to be reduced to $70 \mathrm{~m}$ in the future. Two experimental blasts were performed-Tests A and B (Fig. 1). The blasting geometry was the same for both experiments: burden $2.5 \mathrm{~m}$; spacing $2.5 \mathrm{~m}$; stemming between 1.7 and $2.6 \mathrm{~m}$ and hole diameter $64 \mathrm{~mm}$ (Table 2). Figure 2 shows cross section of the blasthole. For each blast, the boreholes were charged with $1.5,2.5$ and $3.5 \mathrm{~kg}$ of Nitram $5^{[26]}$, respectively. Table 3 shows the basic properties of the explosive that was used for the experiments. The initiation system included 3 nonelectric detonators with 0,300 and $600 \mathrm{~ms}$ delay at the bottom of the boreholes. An electric detonator was used as a source of initiation pulse at the surface. Both soil material and drilling cuttings were combined to be used as stemming.

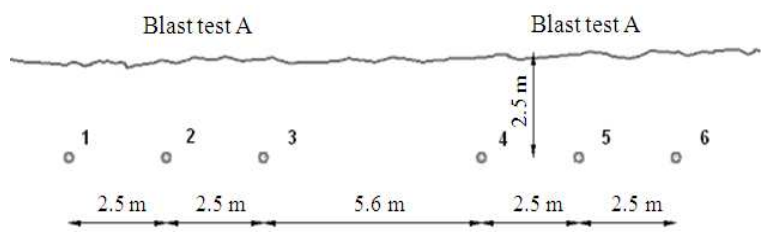

Fig. 1: Plan view of the drilling and blasting pattern

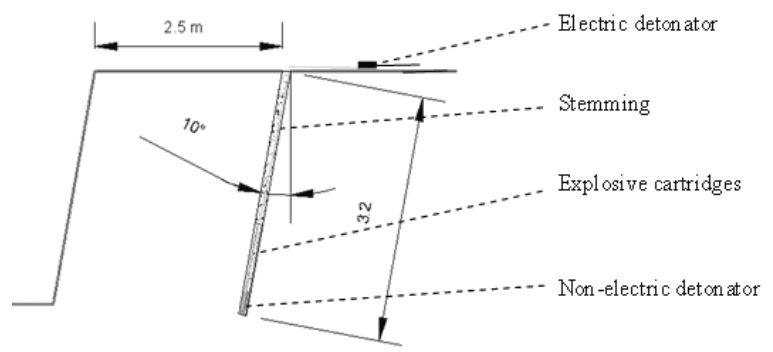

Fig. 2: Cross section of a blasthole in the experimental blasts

Table 2: Experimental blast geometry

\begin{tabular}{lllllll}
\hline $\begin{array}{l}\text { Borehole } \\
\text { diameter }\end{array}$ & $\begin{array}{l}\text { Hole } \\
\text { depth }\end{array}$ & Burden & Spacing & Inclination & Angle & Sub-drilling \\
\hline$[\mathrm{mm}]$ & {$[\mathrm{m}]$} & {$[\mathrm{m}]$} & {$[\mathrm{m}]$} & {$\left[^{\circ}\right]$} & $\left.{ }^{\circ}\right]$ & {$[\mathrm{m}]$} \\
64 & 3.3 & 2.5 & 2.5 & 10 & 80 & 0.2 \\
\hline
\end{tabular}

The ppv data were recorded by six tri-axial geophones. In order to obtain reliable data from in situ tests, the geophones have to be correctly positioned on the ground. As a rule of thumb, geophone coupling method is defined through the particle acceleration. For example, when acceleration does not exceed $0.2 \mathrm{~g}$, where $\mathrm{g}$ is the acceleration of gravity, it is desirable to cover the geophones with sand bags. However, when an acceleration falls between 0.2 and $1 \mathrm{~g}$, either burial or firm anchoring of geophone to the rock mass (soil) is adequate. Geophones are required to be buried or firmly attached when measuring an acceleration greater than $1 \mathrm{~g}^{[27,28]}$.

Figure 3 shows the position of the geophones, while Table 4 shows the technical characteristics of the geophones used for the experiments. The geophone GEO1 was coupled to the rock by concrete, while the other geophones were simply covered by the sandbags (Fig. 4).

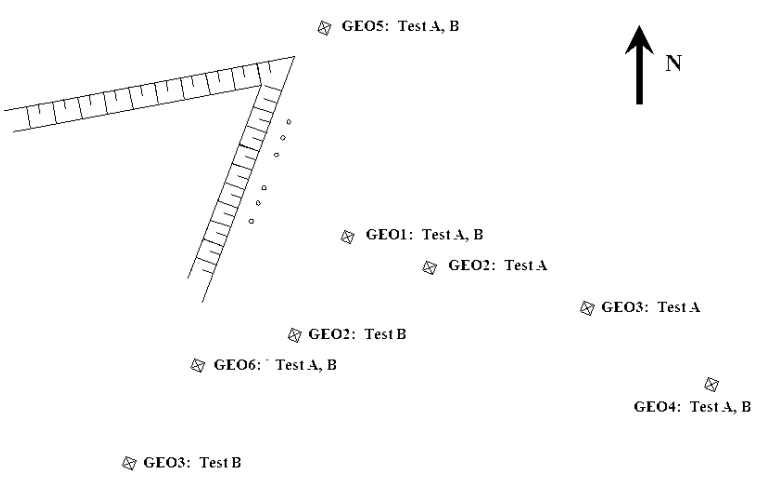

Fig. 3: Location of the geophones
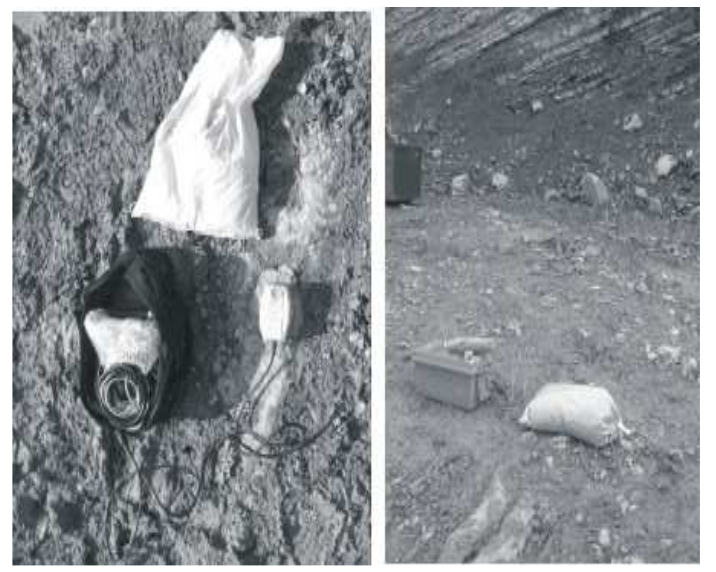

Fig. 4: Geophone GEO1 coupled by concrete (left) and geophone covered by a sandbag (right) 
Am. J. Environ. Sci., 5 (4): 468-474, 2009

Table 3: Properties of the explosive

\begin{tabular}{|c|c|c|c|c|c|c|c|}
\hline \multirow{2}{*}{$\begin{array}{l}\text { Commercial name } \\
\text { Nitram } 5^{[26]}\end{array}$} & Density & Energy liberation & Detonation pressure & VOD & \multirow{2}{*}{$\begin{array}{l}\text { Cartridge length } \\
{[\mathrm{mm}]} \\
475\end{array}$} & \multirow{2}{*}{$\begin{array}{l}\text { Cartridge diameter } \\
{[\mathrm{mm}]} \\
50\end{array}$} & \multirow{2}{*}{$\begin{array}{l}\text { Cartridge mass } \\
{\left[\begin{array}{l}\mathrm{kg}] \\
1.0\end{array}\right.}\end{array}$} \\
\hline & $\begin{array}{l}{\left[\mathrm{kg} \mathrm{m}^{-3}\right]} \\
1200\end{array}$ & $\begin{array}{l}{\left[\mathrm{kJ} \mathrm{kg}^{-1}\right]} \\
3500\end{array}$ & $\begin{array}{l}{[\mathrm{MPa}]} \\
13500\end{array}$ & $\begin{array}{l}{\left[\mathrm{m} \mathrm{sec}^{-1}\right]} \\
5500\end{array}$ & & & \\
\hline \multirow[t]{2}{*}{ Geophone } & \multicolumn{2}{|c|}{ Company and model } & Amplitude range & \multicolumn{2}{|c|}{ Frequency range } & Sample rate & Acustic range \\
\hline & \multicolumn{2}{|c|}{ THOMAS Instrument VMS $2000^{[30]}$} & $\begin{array}{l}{\left[\mathrm{mm} \mathrm{sec}^{-1}\right]} \\
\pm 228\end{array}$ & \multicolumn{2}{|c|}{$[\mathrm{Hz}]$} & $\begin{array}{l}{\left[\text { sample sec }^{-1} \text { ] }\right.} \\
1024\end{array}$ & $\begin{array}{l}{[\mathrm{dB}]} \\
86-141\end{array}$ \\
\hline GEO2-3-6 & \multicolumn{2}{|c|}{ NOMIS Mini-Graph $7000^{[31]}$} & \pm 260 & \multicolumn{2}{|c|}{$2-400$} & 1024 & $92-148$ \\
\hline GEO4 & \multicolumn{2}{|c|}{ BARTEC MR2002-CE ${ }^{[32]}$} & \pm 114 & \multirow{2}{*}{\multicolumn{2}{|c|}{$\begin{array}{l}1-315 \\
2-400\end{array}$}} & 800 & - \\
\hline GEO5 & \multicolumn{2}{|c|}{ NOMIS Mini Supergraph $^{[31]}$} & \pm 260 & & & 1024 to 4096 & $92-148$ \\
\hline
\end{tabular}

Table 5: Results of ppv data recorded at different distances and using different cpd

\begin{tabular}{|c|c|c|c|c|c|c|c|c|}
\hline Geophone & Test & Borehole No. & $\begin{array}{l}\text { ppv R } \\
{\left[\mathrm{mm} \mathrm{sec}^{-1}\right]}\end{array}$ & $\begin{array}{l}\text { ppv T } \\
{\left[\mathrm{mm} \mathrm{sec}^{-1}\right]}\end{array}$ & $\begin{array}{l}\text { ppv V } \\
{\left[\mathrm{mm} \mathrm{sec}^{-1}\right]}\end{array}$ & $\begin{array}{l}\text { ppv max } \\
{\left[\mathrm{mm} \mathrm{sec}^{-1}\right]}\end{array}$ & $\begin{array}{l}\mathrm{cpd} \\
{[\mathrm{kg}]}\end{array}$ & $\begin{array}{l}\mathrm{D} \\
{[\mathrm{m}]}\end{array}$ \\
\hline \multirow[t]{6}{*}{ Geo1 } & $\mathrm{A}$ & 1 & 15.2 & 17.1 & 11.8 & 17.1 & 1.5 & 14 \\
\hline & & 2 & 39.0 & 42.1 & 26.6 & 42.1 & 2.5 & 14 \\
\hline & & 3 & 85.4 & 97.4 & 50.2 & 97.4 & 3.5 & 14 \\
\hline & $\mathrm{B}$ & 4 & 55.7 & 41.6 & 29.7 & 55.7 & 1.5 & 16 \\
\hline & & 5 & 30.9 & 28.6 & 18.7 & 30.9 & 2.5 & 17 \\
\hline & & 6 & 5.9 & 5.5 & 7.3 & 7.3 & 3.5 & 19 \\
\hline \multirow[t]{3}{*}{ Geo2 } & B & 4 & 3.5 & 4.3 & 4.7 & 4.7 & 1.5 & 26 \\
\hline & & 5 & 2.7 & 4.7 & 6.0 & 6.0 & 2.5 & 29 \\
\hline & & 6 & 3.6 & 3.3 & 4.8 & 4.8 & 3.5 & 31 \\
\hline \multirow[t]{6}{*}{ Geo3 } & A & 1 & 3.3 & 1.4 & 1.8 & 3.3 & 1.5 & 50 \\
\hline & & 2 & 4.4 & 2.2 & 2.2 & 4.4 & 2.5 & 50 \\
\hline & & 3 & 4.3 & 3.2 & 2.2 & 4.3 & 3.5 & 50 \\
\hline & B & 4 & 1.0 & 1.4 & 1.7 & 1.7 & 1.5 & 49 \\
\hline & & 5 & 0.8 & 2.4 & 2.2 & 2.4 & 2.5 & 52 \\
\hline & & 6 & 1.3 & 2.0 & 1.7 & 2.0 & 3.5 & 54 \\
\hline \multirow[t]{6}{*}{ Geo4 } & A & 1 & 0.7 & 0.6 & 1.1 & 1.1 & 1.5 & 97 \\
\hline & & 2 & 0.8 & 0.9 & 1.8 & 1.8 & 2.5 & 97 \\
\hline & & 3 & 1.3 & 1.1 & 2.4 & 2.4 & 3.5 & 97 \\
\hline & B & 4 & 0.6 & 0.5 & 0.9 & 0.9 & 1.5 & 98 \\
\hline & & 5 & 0.7 & 1.2 & 1.2 & 1.2 & 2.5 & 98 \\
\hline & & 6 & 1.0 & 1.6 & 1.0 & 1.6 & 3.5 & 98 \\
\hline \multirow[t]{6}{*}{ Geo5 } & A & 1 & 2.8 & 2.3 & 3.7 & 3.7 & 1.5 & 30 \\
\hline & & 2 & 7.1 & 3.2 & 7.7 & 7.7 & 2.5 & 27 \\
\hline & & 3 & 6.9 & 6.9 & 8.6 & 8.6 & 3.5 & 25 \\
\hline & B & 4 & 5.1 & 6.5 & 7.6 & 7.6 & 1.5 & 20 \\
\hline & & 5 & 9.3 & 18.6 & 24.4 & 24.4 & 2.5 & 17 \\
\hline & & 6 & 8.2 & 15.1 & 17.1 & 17.1 & 3.5 & 15 \\
\hline \multirow[t]{6}{*}{ Geo6 } & A & 1 & 7.1 & 12.8 & 9.0 & 12.8 & 1.5 & 22 \\
\hline & & 2 & 9.4 & 13.3 & 11.4 & 13.3 & 2.5 & 25 \\
\hline & & 3 & 5.6 & 8.8 & 7.9 & 8.8 & 3.5 & 27 \\
\hline & B & 4 & 3.7 & 5.3 & 4.4 & 5.3 & 1.5 & 32 \\
\hline & & 5 & 3.3 & 5.2 & 6.1 & 6.1 & 2.5 & 35 \\
\hline & & 6 & 2.7 & 6.5 & 5.7 & 6.5 & 3.5 & 37 \\
\hline
\end{tabular}

\section{RESULTS}

The results of the ppv measurement recorded at all geophones are shown in Table 5. The empirical constants including $\mathrm{K}, \mathrm{n}, \mathrm{m}$ and $\alpha$ were determined by the statistical tool Minitab version $14^{[29]}$. The calculated values for both existing standards and a proposed equation are given in Table 6 . It can be noted that the coefficient of determination $\left(\mathrm{R}^{2}\right)$ varies between 79.2 and $93.1 \%$, while for the Indian Standard ${ }^{[15]}$ value for $\mathrm{R}^{2}$ is $59.9 \%$. All the considered equations but
Rai et al. ${ }^{[18]}$ and Indian Standard ${ }^{[15]}$ have the similar values for Standard Error (SE).

The results obtained by these experiments were compared with the minimum values of ppv suggested by DIN 4150-3 standard ${ }^{[33]}$. Table 7 shows the limits of ppv suggested by the DIN standard for different types of structures.

Figure 5-7 show the relationship between charge per delay (cpd) and distance (D) for different values of peak particle velocity (ppv), i.e., 3,5 and $20 \mathrm{~mm} \mathrm{sec}^{-1}$, respectively. 
Am. J. Environ. Sci., 5 (4): 468-474, 2009

Table 6: Empirical constants (K, n, $m$ and $\alpha$ ), Standard Error (SE) and coefficient of determination $\left(\mathrm{R}^{2}\right)$

\begin{tabular}{|c|c|c|c|c|c|c|}
\hline & $\mathrm{K}$ & $\mathrm{n}$ & $\mathrm{m}$ & $\alpha$ & SE & $\mathrm{R}^{2}$ \\
\hline $\mathrm{USBM}^{[11]}$ & 769.50 & -1.560 & - & - & 0.219 & 81.5 \\
\hline Davies et al. ${ }^{[12]}$ & 1279.70 & -1.610 & 0.405 & - & 0.214 & 83.0 \\
\hline Langefors-Kihlström $^{[13]}$ & 514.50 & 2.000 & - & - & 0.233 & 79.2 \\
\hline Ambraseys-Hendron ${ }^{[14]}$ & 1099.00 & -1.600 & - & - & 0.212 & 82.8 \\
\hline Indian Standard ${ }^{[15]}$ & 68.40 & 1.610 & - & - & 0.323 & 59.9 \\
\hline Ghosh-Daemen $^{[16]}$ & 1166.80 & -1.760 & - & -0.005 & 0.221 & 81.8 \\
\hline Central mining research institute ${ }^{[17]}$ & 418.60 & -10.550 & - & - & 0.219 & 81.5 \\
\hline Rai et al..$^{[18]}$ & 0.54 & 0.167 & - & - & 0.151 & 93.1 \\
\hline Proposed equation & 29607.38 & -0.780 & - & - & 0.219 & 81.6 \\
\hline
\end{tabular}

Table 7: Range of ppv values for different types of structures-DIN 4150-3 standard $^{[33]}$

\begin{tabular}{|c|c|c|c|c|c|}
\hline \multirow[b]{4}{*}{ Line } & \multirow[b]{4}{*}{ Type of structure } & \multicolumn{4}{|c|}{ Vibration velocity (ppv) $\left[\mathrm{mm} \mathrm{sec}^{-1}\right]$} \\
\hline & & \multicolumn{3}{|l|}{ Foundation } & \multirow{3}{*}{$\begin{array}{l}\text { Plane of floor } \\
\text { of uppermost } \\
\text { full storey } \\
\text { Frequency } \\
\text { mixture }\end{array}$} \\
\hline & & \multicolumn{3}{|l|}{ At a frequency of } & \\
\hline & & Less than $10[\mathrm{~Hz}]$ & $10-50[\mathrm{~Hz}]$ & $50-100[\mathrm{~Hz}]^{*}$ & \\
\hline 1 & $\begin{array}{l}\text { Buildings used for commercial purposes, industrial buildings and } \\
\text { buildings of similar design }\end{array}$ & 20 & $20-40$ & $40-50$ & 40 \\
\hline 2 & Dwellings and buildings of similar design and/or use & 5 & $5-15$ & $15-20$ & 15 \\
\hline 3 & $\begin{array}{l}\text { Structures that, because of their particular sensitivity to vibration, } \\
\text { do not correspond to those listed in lines } 1 \text { and } 2 \text { and are of great } \\
\text { intrinsic value (e.g. buildings that are under a preservation order) }\end{array}$ & 3 & $3-8$ & $8-10$ & 8 \\
\hline
\end{tabular}

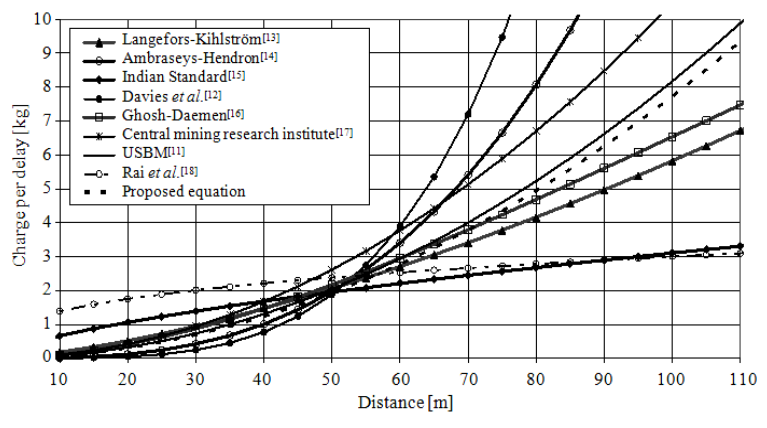

Fig. 5: Charge per delay Vs distance $\left(\mathrm{ppv}=3 \mathrm{~mm} \mathrm{sec}^{-1}\right)$

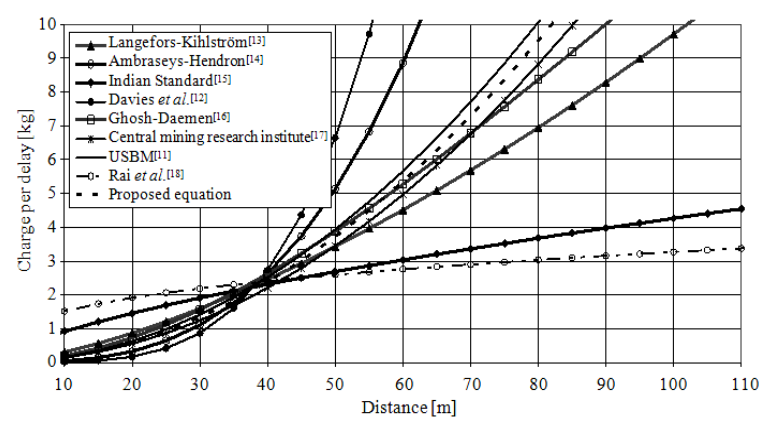

Fig. 6: Charge per delay Vs distance $\left(p p v=5 \mathrm{~mm} \mathrm{sec}^{-1}\right)$

Table 8 summarizes the cpd values calculated at a distance of $60 \mathrm{~m}$.

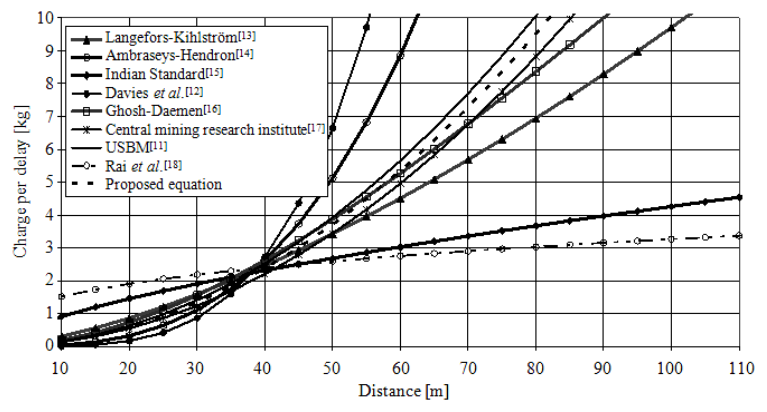

Fig. 7: Charge per delay Vs distance $\left(\mathrm{ppv}=20 \mathrm{~mm} \mathrm{sec}^{-1}\right)$

The proposed equation was compared to other standard equations using a percentage change, which is calculated as follows:

$\%$ change $=\left(\frac{\text { eq. prop. }[\text { cpd] }- \text { other eq. }[\mathrm{cpd}]}{\text { other eq. }[\mathrm{cpd}]}\right) \cdot 100$

It can be noted that cpd values derived by proposed equation are comparable with the results obtained by the existing standards and, in particular, with the most popular equation given by the USBM ${ }^{[11]}$. The Langefors-Kihlström $^{[13]}$ and the Ghosh-Daemen ${ }^{[16]}$ equations give similar results for a low ppv value (3-5 $\mathrm{mm} \mathrm{sec}^{-1}$ ), while the results from the Indian Standard and Rai et al. ${ }^{[18]}$ equations suggest lower cpd. 
Am. J. Environ. Sci., 5 (4): 468-474, 2009

\begin{tabular}{|c|c|c|c|c|}
\hline & $\begin{array}{l}\mathrm{ppv} \\
{\left[\mathrm{mm} \mathrm{sec}^{-1}\right]}\end{array}$ & $\begin{array}{l}\text { Proposed } \\
\text { cpd } \\
{[\mathrm{kg}]}\end{array}$ & $\begin{array}{l}\text { Other } \\
\text { cpd } \\
{[\mathrm{kg}]}\end{array}$ & $\begin{array}{l}\text { Change } \\
{[\%]}\end{array}$ \\
\hline \multirow[t]{3}{*}{$\mathrm{USBM}^{[11]}$} & 3 & 2.8 & 2.9 & -5.4 \\
\hline & 5 & 5.4 & 5.7 & -5.4 \\
\hline & 20 & 31.6 & 33.5 & -5.4 \\
\hline \multirow[t]{3}{*}{ Davies et al..$^{[12]}$} & 3 & 2.8 & 3.9 & -28.5 \\
\hline & 5 & 5.4 & 13.7 & -61.0 \\
\hline & 20 & 31.6 & 421.5 & -92.5 \\
\hline \multirow[t]{3}{*}{ Langefors-Kihlström $^{[13]}$} & 3 & 2.8 & 2.7 & 2.8 \\
\hline & 5 & 5.4 & 4.5 & 18.7 \\
\hline & 20 & 31.6 & 18.1 & 73.5 \\
\hline \multirow[t]{3}{*}{ Ambraseys-Hendron ${ }^{[14]}$} & 3 & 2.8 & 3.4 & -18.3 \\
\hline & 5 & 5.4 & 8.9 & -39.6 \\
\hline & 20 & 31.6 & 118.9 & -73.4 \\
\hline \multirow[t]{3}{*}{ Indian standard $^{[15]}$} & 3 & 2.8 & 2.2 & 25.8 \\
\hline & 5 & 5.4 & 3.0 & 76.5 \\
\hline & 20 & 31.6 & 7.2 & 342.0 \\
\hline \multirow[t]{3}{*}{ Ghosh-Daemen ${ }^{[16]}$} & 3 & 2.8 & 3.0 & -5.8 \\
\hline & 5 & 5.4 & 5.3 & 1.6 \\
\hline & 20 & 31.6 & 25.4 & 24.5 \\
\hline \multirow{3}{*}{$\begin{array}{l}\text { Central mining } \\
\text { research institute }^{[17]}\end{array}$} & 3 & 2.8 & 3.8 & -26.2 \\
\hline & 5 & 5.4 & 5.0 & 7.8 \\
\hline & 20 & 31.6 & 19.2 & 65.1 \\
\hline \multirow[t]{3}{*}{ Rai et $_{\text {al }} .^{[18]}$} & 3 & 2.8 & 2.5 & 9.8 \\
\hline & 5 & 5.4 & 2.8 & 94.1 \\
\hline & 20 & 31.6 & 3.5 & 810.6 \\
\hline
\end{tabular}

The Central Mining Research Institute ${ }^{[17]}$ equation gives comparable results to the proposed equation, but only for high ppv values. Finally, the AmbraseysHendron $^{[14]}$ and Davies et al. ${ }^{[12]}$ equations provide remarkable different cpd values.

\section{CONCLUSION}

The experimental study was carried out in order to determine the vibration level at the marlstone quarry in northern Italy. Based on the results of the experiments, a new blasting predictor for the peak particle velocity was introduced. The comparative analysis between the results of proposed predictor and the current equations (standards) was also performed.

The results of the study indicate that the proposed equation gives similar results to those obtained by widely used USBM $^{[11]}$ standard. The derived equation is a site-specific and it should be updated/revised if there is a significant change of ppv values with the future development of the quarry.

\section{ACKNOWLEDGMENT}

Researchers acknowledge Holcim Italia SpA for their support during the experimental tests.

\section{REFERENCES}

1. Singh, T.N. and V. Singh, 2005. An intelligent approach to prediction and control ground vibration in mines. Geotech. Geologic. Eng., 23: 249-262. DOI: $10.1007 / \mathrm{s} 10706-004-7068-\mathrm{x}$

2. Raina, A.K., A. Haldar, A.K. Chakraborty, P.B. Choudhury and R.M. Bandyopadhyay, 2004. Human response to blast-induced vibration and airoverpressure: An Indian scenario. Bull. Eng. Geol. Environ., 63: 209-214. DOI: 10.1007/s10064-0040228-7

3. Siskind, D., 2000. Vibrations from blasting. International Society of Explosives Engineers Publisher, ISBN: 10: 1892396114, pp: 120.

4. Oriard, L.L., 1989. The scale of effects in evaluating vibration damage potential. Proceeding of the 15th SEE Conference on Explosives and Blasting Techniques, Feb. 1989, Society of Explosives Engineers, pp: 161-176. http://www.isee.org/tis/Proceed/General/89gen/891 2g.pdf

5. Rustan, A., 1998. Rock Blasting terms and Symbols. Taylor and Francis, Inc., Rotterdam, ISBN: 13: 9789054104414, pp: 204.

6. Bhandari, S. and A.A. Balkema, 1997. Engineering Rock Blasting Operations. Netherlands/Brookfield, USA Publishers, Rotterdam, ISBN: 9054106638, pp: 400.

7. Rossmanith, H.P., V. Hochholdinger-Arsic and K. Uenishi, 2005. Understanding size and boundary effects in scaled model blast-plane problems. Int. J. Blast. Fragment., 9: 93-125. DOI: 10.1080/13855140500296671

8. Valdivia, C., M. Vega, C.R. Scherpenisse and W.R. Adamson, 2003. Vibration simulation method to control stability in the Northeast corner of Escondia mine. Int. J. Blast. Fragment., 7: 63-78. http://www.informaworld.com/smpp/ftinterface?co ntent $=$ a 714016420\&rt=0\&format $=$ pdf

9. Nicholls, H.R., C.F. Johnson and W.I. Duvall, 1971. Blasting vibrations and their effects on structures.

http://www.osti.gov/energycitations/product.biblio. jsp?osti_id=7256720

10. Kuzu, C., H. Ergin, 2005. An assessment of environmental impacts of quarry-blasting operation: A case study in Istanbul, Turkey. Environ. Geol., 48: 211-217. DOI: 10.1007/s00254-005-1291-5

11. Duvall, W.I. and B. Petkof, 1959. Spherical propagation of explosion generated strain pulses in rock. US Bureau of Mines, RI 5483. http://www.isee.org/tis/Invest/46_60/RI5483.pdf 
12. Davies, B., I.W. Farmer and P.B. Attewell, 1964. Ground vibrations from shallow subsurface blasts. Engineer, 217: 553-559.

13. Langefors, U. and B. Kihlstrom, 1973. The Modern Technique of Rock Blasting. 2nd Edn., Wiley Publisher, New York, pp: 405. http://books.google.com.pk/books?id=HXfUOwA ACAAJ\&dq=The+Modern+Technique+of+Rock+ Blasting.

14. Ambraseys, N.R. and A.J. Hendron, 1968. Dynamic Behavior of Rock Masses. In: Rock Mechanics in Engineering Practice, Stagg, K.G. and O.C. Zeinkiewicz. Wiley, London, pp: 442. http://www.sciencemag.org/cgi/content/citation/16 3/3869/804-a

15. Indian Standards Institute, 1973. Criteria for safety and design of structures subjected to underground blast. ISI Bulletin IS-6922. http://www.ieiapsc.org.in/Standa 1.htm\#6922

16. Ghosh, A. and J.J.K. Daemen, 1983. A simple new blast vibration predictor (based on wave propagation laws). Proceeding of the 24th US Symposium on Rock Mechanics, June 20-23, Texas A and M University and Association of Engineering Geologists, College Station, Tex., USA., pp: 151-161.

17. Roy, P.P., 1991. Vibration control in an opencast mine based on improved blast vibration predictors. Min. Sci. Technol., 12: 157-165. http://dx.doi.org/10.1016/0167-9031(91)91642-U

18. Rai, R., B.K. Shrivastva and T.N. Singh, 2005. Prediction of maximum safe charge per delay in surface mining. Min. Technol., 114: 227-231. http://www.citeulike.org/article/446269

19. Birch, W.J. and R. Chaffer, 1983. Prediction of ground vibrations from blasting on opencast sites. Trans. Inst. Min. Metallurgy, 4: 103-107. http://md1.csa.com/partners/viewrecord.php?requeste $\mathrm{r}=\mathrm{gs} \&$ collection $=\mathrm{TRD} \& \mathrm{recid}=8323754 \mathrm{AN} \& \mathrm{q}=$ Predic tion+of+ground+vibrations+from+blasting+on+openc ast + sites\&uid $=787199305 \&$ setcookie $=$ yes

20. Singh, B. and P.P. Roy, 1993. Blasting in Ground Excavation and Mines. Balkema, Rotterdam Publisher, ISBN: 9061919568, pp: 188.

21. Yun, X.Y., X.L. Yang and H.S. Mitri, 2007. Blast vibration control in highway construction near a cultural heritage site. Int. J. Min. Reclamat. Environ., 21: 75-84. http://direct.bl.uk/bld/PlaceOrder.do?UIN=203277 361\&ETOC $=$ RN\& from $=$ searchengine

22. Duvall, W.I. and D.E. Fogelson, 1962. Review of criteria for estimating damages to residences from blasting vibrations. US Bureau of Mines, RI 5968, 19. http://www.isee.org/tis/Invest/46_60/RI5968.pdf
23. Duvall, W.I., J.F. Devine, C.F. Johnson and A.V.C. Meyer, 1963. Vibration from blasting at Iowa limestone quarries. US Bureau of Mines, RI 6270, 28. http://www.isee.org/tis/Invest/60_63/RI6270.pdf

24. Daemen, J.J.K., Barkley, R.C., A. Ghosh, C.R. Morlock and S.A. Shoop, 1983. Ground and air vibrations from caused by surface blasting. Vol. 1. http://www.osti.gov/energycitations/product.biblio. jsp?osti_id $=6613826$

25. Vanbrabant, F., E.P. Chacoâ and L. Quinä, 2002. P and $\mathrm{S}$ mach waves generated by the detonation of a cylindrical explosive charge-experiments and simulations. Int. J. Blast. Fragment., 6: 21-35. http://cat.inist.fr/?aModele $=$ afficheN\&cpsidt $=1388$ 6166.

26. Nitro-Bickford, 2009. Emulsions NITRAM 5. http://www.nitrobickford.fr

27. ISEE., 1999. Field practice guidelines for blasting seismograph.

http://www.isee.org/sections/99FldPractStandards Approved.pdf

28. Adhikari, G.R., A.I. Theresraj and R.N. Gupta, 2005. Influence of transducer-ground coupling on vibration measurements. Int. J. Blast. Fragment., 9: 79-92.

http://cat.inist.fr/?aModele $=$ afficheN\&cpsidt $=1723$ 8659

29. MINITAB, 2007. Minitab 14. http://www.minitab.com

30. Thomas Instruments, 2009. Thomas instruments VMS 2000.

http://vibration.com/v2/index.php?main_page=pro duct_info\&cPath $=1 \&$ products_id $=1$

31. NOMIS., 2007. Nomis Mini-Graph 7000, Mini Supergraph. http://www.nomis.com/index.php?option=content $\&$ task $=$ view $\&$ id $=25 \&$ Itemid $=143$

32. BARTEC., $2009 . \quad$ Bartec MR2002. http://www.bartec.de/homepage/deu/downloads/pr odukte/200_seismik/App_Brochure_SI_NPP\%20.p df

33. DIN 4150-3, 1999. Structural vibration-Effects of vibration on structures. http://webstore.ansi.org/RecordDetail.aspx?sku=DI $\mathrm{N}+4150-3 \% 3 \mathrm{~A} 1999$ 